\title{
Estimating and Forecasting Volatility of Financial Markets Using Asymmetric GARCH Models: An Application on Turkish Financial Markets
}

\author{
R. İlker Gökbulut ${ }^{1} \&$ Mehmet Pekkaya ${ }^{1}$ \\ ${ }^{1}$ Faculty of Economics and Administrative Sciences, Bulent Ecevit University, Zonguldak, Turkey \\ Correspondence: R. İlker Gökbulut, Bulent Ecevit University, IIBF, Uluslararası Ticaret ve İşletmecilik Bölümü, \\ Incivez, Zonguldak, Turkey. Tel: 90-372-257-4010 ext. 1574. E-mail: rigokbulut@gmail.com
}

Received: February 5, 2014

Accepted: February 12, 2014

Online Published: March 25, 2014

doi: 10.5539/ijef.v6n4p23

URL: http://dx.doi.org/10.5539/ijef.v6n4p23

\begin{abstract}
Volatility in financial markets, particularly stock exchange markets, is an important issue that concerns theorists and practitioners. Over the past 30 years, there has been a vast literature for modeling the temporal dependencies in volatility of financial markets. Also, more recently researches have been examining the asymmetry and non-linear properties in variance of financial assets, rather than the conditional mean. In this study, a comprehensive empirical analysis of the mean return and conditional variance of Turkish Financial Markets is performed by using various GARCH models. CGARCH and TGARCH appear to be superior for modeling the volatility of financial instruments in Turkey during the years 2002-2014. It is also found that return series of all markets include; leptokurtosis, asymmetry, volatility clustering, and long memory.
\end{abstract}

Keywords: asymmetric GARCH, volatility, financial markets, forecasting, BIST

\section{Introduction}

Forecasting and modeling volatility is an important issue of research in financial markets. Much empirical work has been done in improving volatility models, since better forecasts translate into better pricing of financial assets and better risk management. On the other hand, stock market volatility has been intensively studied in the last three decades with a great deal of empirical work being done.

Volatility clustering (Note 1) and leptokurtosis are common observation in financial time series (Mandelbrot, 1963). It is well known that financial returns have non-normal distribution which tends to have fat-tailed. Mandelbrot (1963) strongly rejected normal distribution for data of asset returns, conjecturing that financial return processes behave like non-Gaussian stable processes (commonly referred to as "Stable Paretian" distributions).

Another phenomenon often encountered is the leverage effect. Black (1976) first noted that, changes in stock returns usually display a tendency to be negatively correlated with the changes in returns volatility i.e., volatility tends to rise in response to "bad news" and to fall in response to "good news". This phenomenon is termed the "leverage effect" and can only be partially interpreted by fixed costs such as financial and operating leverage (Note 2). The asymmetry present in the volatility of stock returns is too large to be fully explained by leverage effect.

Financial time series are often available at a higher frequency than the other time series (e.g., macroeconomic) and many high-frequency financial time series have been shown to exhibit the property of 'long-memory' (Note 3) (Harris \& Sollis, 2003). The long range dependence or the long memory implies that the present information has a persistent impact on future counts. Note that the long memory property is related to the sampling frequency of a time series.

Another important feature of many financial time series is the time-varying volatility or 'heteroscedasticity' of the data. The term "heteroscedasticity" refers to changing volatility (i.e., variance).

These characteristics of variance cannot be explained with linear models such as the RW (Note 4) and OLS and independently introduced the AutoRegressive Conditional Heteroscedasticity (ARCH) and the generalized ARCH (GARCH) models, which specifically allows for changing conditional variance. The heteroscedasticity in 
stock returns is explained through examining the behaviors of the conditioning information variables in relation to the ARCH effects. After Engle (1982) and Bollerslev (1986), ARCH models have been widely employed in the analyses of financial markets. The effects of heteroscedasticity have been evidenced especially for high-frequency returns, whose distributions are heavy-peaked and tailed.

Efficient market hypothesis stand for that nobody can take caution to his investments by using past price of assets. However, it is known that there is no market accepted as strongly efficient. Accordingly, until the markets satisfy efficient market conditions, researches show that volatilities and past price of assets may deliver signals for future behavior of asset value. It is accepted that, empirical time series has the characteristics mentioned above (Miron \& Tudor, 2010; Peters, 2001).

Moreover, increase in volatilities of assets is thought as increase in risk which may produces financial crises. Thus, volatility is very noteworthy financial instrument for investing decisions. Investors take care on volatility not only for spot price of asset but also for derivative valuations, hedging strategies and portfolio allocation. Policy makers also interested in volatility because of tendency to conserving the stability of financial markets.

The aim of this study is whether volatility of Turkish financial instruments can be modeled by asymmetric GARCH approaches and which GARCH process is appropriate for modeling the volatility of Turkish financial markets.

The paper is organized as follows: In section 2, literature review and GARCH Models are studied. In section 3, stages of modeling Turkish financial instruments by using GARCH process and empirical results are given. In section 4 , concluding remarks is presented.

\section{GARCH Type Models and Literature Review}

\subsection{GARCH Models}

During last three decades, lots of articles have been studied for modeling conditional volatility especially for financial markets. Engle (1982) offered modeling conditional variance with ARCH processes which is a linear function of lagged squared residuals. The general model of $\operatorname{ARCH}(q)$ process is as follows (Engle, 1982):

$$
\sigma_{t}^{2}=\alpha_{0}+\sum_{i=1}^{q} \alpha_{i} \varepsilon_{t-i}^{2}
$$

where, $\alpha_{0}$ is mean, $\sigma_{t}^{2}$ is conditional volatility and $\varepsilon_{t}$ is white noise representing the residuals of the time series.

Bollerslev (1986) introduced GARCH model, which has lagged squared residuals and lagged variances. The general model of $\operatorname{GARCH}(p, q)$ process is as follows (Bollerslev, 1986):

$$
\sigma_{t}^{2}=\alpha_{0}+\sum_{i=1}^{q} \alpha_{i} \varepsilon_{t-i}^{2}+\sum_{j=1}^{p} \beta_{i} \sigma_{t-j}^{2}
$$

where $\mathrm{i}=0,1,2, \ldots, p, \sigma_{t}^{2}$ is conditional volatility, $\varepsilon_{t}$ residuals and $\sigma_{t-j}^{2}$ is lagged conditional volatility that is the difference of GARCH from the ARCH. Then, $\alpha_{i}$ and $\varepsilon_{t-j}^{2}$ are known as ARCH components, $\beta_{j}$ and $\sigma_{t-j}^{2}$ are known as GARCH components and $\alpha_{0}, \alpha_{i}$ and $\beta_{i}$ are positive. GARCH models indicates that, volatility of asset returns exhibit volatility clustering which is seen from lagged variance terms.

These models can capture the volatility when their distribution is symmetric. Classical ARCH and GARCH model works for assumption that all of the shock effects on volatility have symmetric distribution. However, series of asset return are usually have skewed distribution which force to use asymmetric GARCH models. GARCH models can be used in option markets to forecast volatility for securities and the volatility is vital factor for formation of option prices. Moreover, Fernandez and Arago (2003) conclude volatility transmission mechanism across European stock markets as asymmetric.

Asymmetric GARCH models can be listed as Exponential GARCH (EGARCH) model by Nelson (1991), GJR model by Glosten et al. (1993), Threshold GARCH (TGARCH) model by Zakoian (1994), Asymmetric Power GARCH (APGARCH or PGARCH) model by Ding et al. (1993), Quadratic GARCH (QGARCH) model, Conditional AutoRegresive Range (CARR), Dynamic Asymmetric (DAGARCH) by Caporin and McAleer (2006), Integrated GARCH (IGARCH), Component GARCH (CGARCH), Fractional Integrated GARCH (FIGARCH), Volatility Switching ARCH (VS-ARCH) so on.

Nelson (1991) introduced one of the well-known asymmetric GARCH model as EGARCH by working up Exponential ARCH. EGARCH can be expressed as follows (Yalama \& Sevil, 2008; Dallah, 2011).

$$
\ln \sigma_{t}^{2}=\alpha_{0}+\sum_{i=1}^{q}\left(\alpha_{i}\left|\frac{\varepsilon_{t-i}}{\sigma_{t-i}}\right|+\gamma_{i}\left|\frac{\varepsilon_{t-i}}{\sigma_{t-i}}\right|\right)+\sum_{j=1}^{p} \beta_{j} \ln \left(\sigma_{t-j}^{2}\right)
$$


The presence of leverage effect can be tested by hypotheses of $\gamma_{i}<0$. The impact is asymmetric if $\gamma_{i} \neq 0$ and no leverage effect exists if $\gamma_{i}=0$.

GJR model for GARCH is modeled by Golesten et al. (1993) as follows (Lee, 2009).

$$
\sigma_{t}^{2}=\alpha_{0}+\sum_{i=1}^{q}\left(\alpha_{i} \varepsilon_{t-i}^{2}+\gamma_{i} I_{t-i} \varepsilon_{t-i}^{2}\right)+\sum_{j=1}^{p} \beta_{j} \sigma_{t-j}^{2} ; \quad I_{t-i}= \begin{cases}1 & \varepsilon_{t-i}<0 \\ 0 & \varepsilon_{t-i} \geq 0\end{cases}
$$

When $\varepsilon_{t-j}$ is positive, the total effects on conditional variance are given by $\alpha_{i} \varepsilon_{t-j}^{2}$; when $\varepsilon_{t-j}$ is negative, the total effects on conditional variance are given by $\left(\alpha_{i}+\gamma_{i}\right) \varepsilon_{t-j}^{2}$.

TGARCH is similar to GRJ in using dummy variables but using standard deviations instead of variance. TGARCH is modeled by Zakoian (1994) as below:

$$
\sigma_{t}=\alpha_{0}+\sum_{i=1}^{q}\left(\alpha_{i} \varepsilon_{t-i}+\gamma_{i} I_{t-i} \varepsilon_{t-i}\right)+\sum_{j=1}^{p} \beta_{j} \sigma_{t-j} ; I_{t-i}= \begin{cases}1 & \varepsilon_{t-i}<0 \\ 0 & \varepsilon_{t-i} \geq 0\end{cases}
$$

This first power of variance shows that TARCH model deals with conditional standard deviations. GJR and TGARCH model indicates that, there is leverage effects which is represented by $I$ term can be accepted in variance determination. Both for GJR and TGARCH models as for EGARCH, $\varepsilon_{t-j}<0$ (good news) and $\varepsilon_{t-j}>0$ (bad news) have different effects on conditional variance.

APGARCH is modeled by Ding et al. (1993) as follows:

$$
\sigma_{t}^{\delta}=\alpha_{0}+\sum_{i=1}^{q} \alpha_{i}\left(\left|\varepsilon_{t-i}\right|-\gamma_{i}\left|\varepsilon_{t-i}\right|\right)^{\delta}+\sum_{j=1}^{p} \beta_{j} \sigma_{t-j}^{\delta}
$$

where $\alpha_{0}>0, \delta \geq 0, \beta_{j} \geq 0, \alpha_{i} \geq 0,-1<\gamma_{i}<1$ and $\gamma_{i}$ reflects the leverage effect.

APARCH model is an key model and it can be adapted to seven other ARCH models, which are ARCH (when $\delta$ $=2, \gamma_{i}=0$ and $\beta_{j}=0$ ), GARCH (when $\delta=2$ and $\gamma_{i}=0$ ), Taylor Schwert's GARCH (when $\delta=1$ and $\gamma_{i}=0$ ), GJR (when $\delta=2$ ), TARCH (when $\delta=1$ ), NARCH (when $\gamma_{i}=0$ and $\beta_{j}=0$ ), Log-ARCH (when $\delta \rightarrow 0$ ) (Peters, 2001).

CGARCH is modeled by Engle and Lee (1993) for decompose variance into a temporary or a permanent component. CGARCH can be expressed as follows (Chena \& Shen, 2004, p. 205; Ane, 2006,p. 441; Grier \& Perry, 1998);

$$
\begin{gathered}
\sigma_{t}^{2}=q_{t}+\alpha\left(\varepsilon_{t-1}^{2}-q_{t-1}\right)+\beta\left(\sigma_{t-1}^{2}-q_{t-1}\right) \\
q_{t}=\alpha_{0}+\rho\left(q_{t-i}-\alpha_{0}\right)+\phi\left(\varepsilon_{t-1}^{2}-\sigma_{t-1}^{2}\right)
\end{gathered}
$$

Where, as $\alpha$ and $\beta$ terms stands for short run memory, $q_{t}$ especially $\rho$ term stands for long memory where

$$
0<\alpha+\beta<\rho \leq 1 \text { and } 0<\varphi<\beta<1 .
$$

Asymmetric CGARCH can be expressed as follows;

$$
\begin{gathered}
\sigma_{t}^{2}=q_{t}+\alpha\left(\varepsilon_{t-1}^{2}-q_{t-1}\right)+\gamma\left(\varepsilon_{t-1}^{2}-q_{t-1}\right)+\beta\left(\sigma_{t-1}^{2}-q_{t-1}\right) \\
q_{t}=\alpha_{0}+\rho\left(q_{t-i}-\alpha_{0}\right)+\phi\left(\varepsilon_{t-1}^{2}-\sigma_{t-1}^{2}\right)
\end{gathered}
$$

\subsection{Financial Markets Volatility Forecasting Performance of GARCH Models}

Santis and Imrohoroglu (1997) investigated stock markets, totally 18 countries which are located three different geographical regions with benchmark 4 markets. They found that volatility level and conditional probability of large price changes are higher in emerging markets than mature ones. Wang and Yang (2009), found asymmetric volatility in the exchange rates of Australian Dollar, British Pound and Japan Yen all against US Dollar and found no clear economic reasons for asymmetric volatility but base-currency effect and central bank intervention effect. Thus, markets should be considered according to their feature for modeling of their volatility.

Lee (2009), examined the ability of symmetric and asymmetric GARCH models for forecasting weekly Korean Stock Price Index return. The out of sample forecasting ability tests indicate that no single model is clearly outperforming to each other and even asymmetric GARCH models namely GJR and QGARCH have not get significant difference from symmetric GARCH model. Hien (2008) also did not find statistically significant asymmetric parameters for TARCH $(1,1)$ and EGARCH $(1,1)$ on Vietnam Stock Market. Moreover, Angabini, and Wasiuzzaman (2011) determined the symmetric GARCH model has outperformed to two asymmetric GARCH models (EGARCH and GRJ) despite the presence of asymmetric and leverage effect on Malaysian 
Stock Market with respect to the global financial crisis of 2007/2008. These two asymmetric GARCH models produced the same results.

On the other hand, Miron and Tudor (2010) used U.S. and Romanian daily stock return data and found that EGARCH model exhibits generally lower forecast errors and more accurate than the estimates given by the other asymmetric GARCH models such as TGARCH and PGARCH. EGARCH model with student-t distribution out perform better than the classic GARCH model on application to Chinese Stock Market Indices (Su, 2010). Yalama and Sevil (2008) studied 7 different GARCH models to forecast in sample of daily stock market volatility in 10 different countries. According to results, GARCH models have different performance country to country and with respect to average performance in order EGARCH, PARCH, TARCH, IGARCH, GARCH, GARCH-M are the better models. Awartani and Corradi (2005) used S\&P-500 Index to examine the out of sample predictive ability of 10 different GARCH models for six different prediction horizons. Results show that, there is a clear evidence that asymmetric GARCH models play a crucial role in volatility predictions and the RiskMetrics exponential smoothing model seems to be the model with the lowest predictive ability. Kovacic (2008) found the forecasting performance of asymmetric GJR and TGARCH models is better than symmetric GARCH models according to the in-sample statistics and out-of-sample forecasts on application to Macedonian Stock Index.

Sandoval (2006), gets daily exchange rate series of 7 countries in Asia and Latin America for analyzing symmetric and asymmetric GARCH models. Results show that, emerging market exchange rates did not show a statistically significant better forecast among symmetric (GARCH) and asymmetric (GJR and EGARCH) GARCH models. Balaban (2004) get US Dollar-Deutsche Mark exchange rates for employing symmetric and asymmetric error statistics to evaluate the monthly out-of-sample forecasting accuracy of symmetric ARCH GARCH models and asymmetric EGARCH-GRJ models. Results show that, classic symmetric GARCH provides relatively good forecasts of whereas the asymmetric GJR-GARCH model seems to be a poor alternative. However, Dallah (2011) investigated the volatility of Nigerian Currency Naira against four major developed World currencies. Comparisons of out of sample volatility forecasting show that an TGARCH model which is an asymmetric GARCH model outperform to its competitors in case of US Dollar and the Japanese Yen while the GARCH model is suitable for the British Pound and no clear cut winner for Euro.

CGARCH assumes that, the volatility consists of two components. One of them is the long-run volatility component whose shocks are highly persistent and the other one is the short-run volatility component whose shocks are less persistent (Watanabe \& Harada, 2006). Watanabe and Harada (2006) investigated effect of Bank of Japan intervention on the Yen / US Dollar exchange rate volatility using data from 1991 to 2003. According to the study, the GARCH and the CGARCH models led to similar results for the effect of intervention on the level of the yen/dollar exchange rate. This model can be used for decompose inflation uncertainty into a temporary or a permanent component and whether past inflation affect long-run uncertainty. For this purpose, Kontonikas (2004) has taken seasonally adjusted logarithmic difference of consumer price index of UK for inflation data monthly and quarterly from 1972 to 2002. Results of study showed that, the post-targeting period UK inflation is substantially less persistent and less variable. Study also showed that a direct negative impact from inflation targeting on long-run uncertainty can be identified. Chen and Shen (2004) have taken daily Twain Exchange rate from 1988 to 2003 . They stated that the influence of the jumps was short-lived and only had a temporary effect on the exchange rate volatility except 1997 Asian crisis which has permanent effect on Taiwan's exchange rate according to CGARCH-Jump model. CGARCH-Jump model was preferred for identifying 172 jump dates among the data set, besides time-varying conditional volatility.

Kang et al. (2009) studied three crude oil spot daily closing prices over the period from January 6, 1992 to December 29, 2006 and the last one year's data are used to evaluate out-of-sample volatility forecasts. According to results a volatility persistence or long memory stated in the three crude oil prices with using conditional volatility models. Namely, the CGARCH and FIGARCH models which contain long memory are better equipped to capture persistence than are the GARCH and IGARCH models. Ane (2004) took data of 4 different sector 14 stock exchange of Hang Seng Index from 1990 to 2004. The empirical investigation states the superiority of the general CGARCH over the GARCH model. The trend is found to have a very high level of persistence. The results indicate that the GARCH model provides better short-run forecasts from one-day ahead to five-day-ahead at the utmost, but for longer (medium or long term) forecasting horizons, the CGARCH model is unquestionably selected. 


\subsection{Volatility of Financial Markets in Turkey}

Turkey has developing market and not stable, so experience volatilities more severe. Leverage effect is perceived and decreases are harsher (Mazıbaş, 2011), volatility shocks persist longer for last years (Çağıl \& Okur, 2010) in Istanbul Stock Exchange (ISE-BIST). Yalama and Sevil (2008) determined orderly EGARCH, PARCH, TARCH, CGARCH, GARCH, IGARCH and GARCH-M from best forecasting model to worst one for ISE-100 Index volatility.

Gökçe (2001) has studied ARCH-class models to estimate the appropriate model for forecasting volatility in BIST. In his study, which covers a period from January 2, 1989 to December 31, 1997 with 2245 daily observation, he found that the best fitting model for making forecast and modelling on BIST 100-Index is GARCH $(1,1)$. Besides, a strong and positive relationship between daily trading volume and daily rate of return has been found in the study.

Aydın (2003) has analyzed the volatility behavior of the Istanbul Stock-Exchange 30-Index (Note 5), which includes 30 leading Turkish companies. In Aydın's study, it is observed that there are non-normality, volatility clusters, negative skewness, large kurtosis, and autocorrelation in the financial time series data. Therefore, he has applied EWMA and Generalized ARCH models on modelling the index volatility. His study has put forward that the best fitting model is $\operatorname{GARCH}(1,1)$ and only one-day effect has been observed both for EWMA and GARCH models.

Akgün and Sayyan (2005) have examined the asymmetric response of stock returns in BIST-30 (Note 6) to news by using Asymmetric Conditional Heteroskedasticity models (EGARCH, GJR, APARCH, FIEGARCH, FIAPARCH) for the period January 4, 2000 to April 25, 2005. Their findings show that forecasting volatility in ISE-30 stock returns with Asymmetric Conditional Heteroskedasticity models especially APARCH and FIAPARCH models provides the most accurate volatility forecasts. Authors also claimed that using student-t or skewed student-t distribution instead of normal distribution is more appropriate in modelling and forecasting of financial data with negative skewness and large kurtosis.

Asymmetric conditional volatility models are found more appropriate for US Dollar to Turkish Lira exchange rate (Kıran, 2011). Öztürk (2010) determined TGARCH model for best suitable volatility model for US Dollar to Turkish Lira exchange rate.

\section{Empirical Application}

\subsection{Data}

The main summary statistics of daily return series of BIST-100 Index data (Note 7), interest rate and foreign exchange rate basket (Note 8) are presented in Table 1. These data is taken from CBRT (2014). Our sample data covers the period which starts with the beginning of trading Euro (02/01/2002) and ends 04/02/2014 with 3027 observation of trading days.

Table 1. Descriptive statistics

\begin{tabular}{lccc}
\hline & BIST & Interest Rate & Exchange Rate \\
\hline Mean & 0.000469 & 0.000228 & 0.0000941 \\
Median & 0.00094 & -0.000189 & 0.0000861 \\
Maximum & 0.101516 & 0.055404 & 0.073751 \\
Minimum & -0.11313 & -0.09038 & -0.051902 \\
Std. Dev. & 0.014879 & 0.007967 & 0.004998 \\
Skewness & -0.292 & 0.354732 & 0.801116 \\
Kurtosis & 9.516437 & 13.21321 & 48.37745 \\
Jarque-Bera & 5398.78 & 13219.55 & 260029.4 \\
Probability & 0.0000 & 0.0000 & 0.0000 \\
Sum & 1.421164 & 0.689936 & 0.284895 \\
Sum Sq. Dev. & 0.669867 & 0.19209 & 0.075596 \\
Observations & 3027 & 3027 & 3027 \\
\hline
\end{tabular}

In all return series, skewnesses and excess kurtoses are clearly observed, leading to a high valued Jarque and Bera tests which indicate non-normality of the distribution. The sample kurtoses are greater than three, meaning that return distributions have excess kurtosis since all return series are leptokurtic and excess skewnesses are also 
observed for the three return series. Exchange rate and interest rate series have positive skewness implying that the distribution has a long right tail. On the other hand, the return series of stock returns have negative skewness implying that the distributions have a long left tail. These are the main characteristics observed from financial data.

BIST100

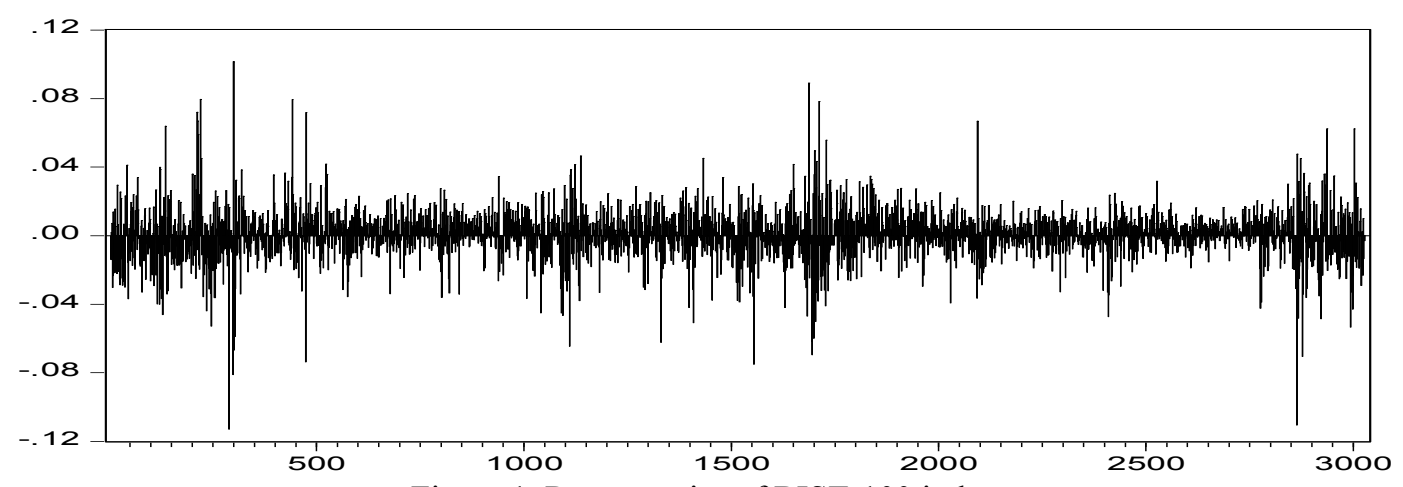

Figure 1. Return series of BIST-100 index

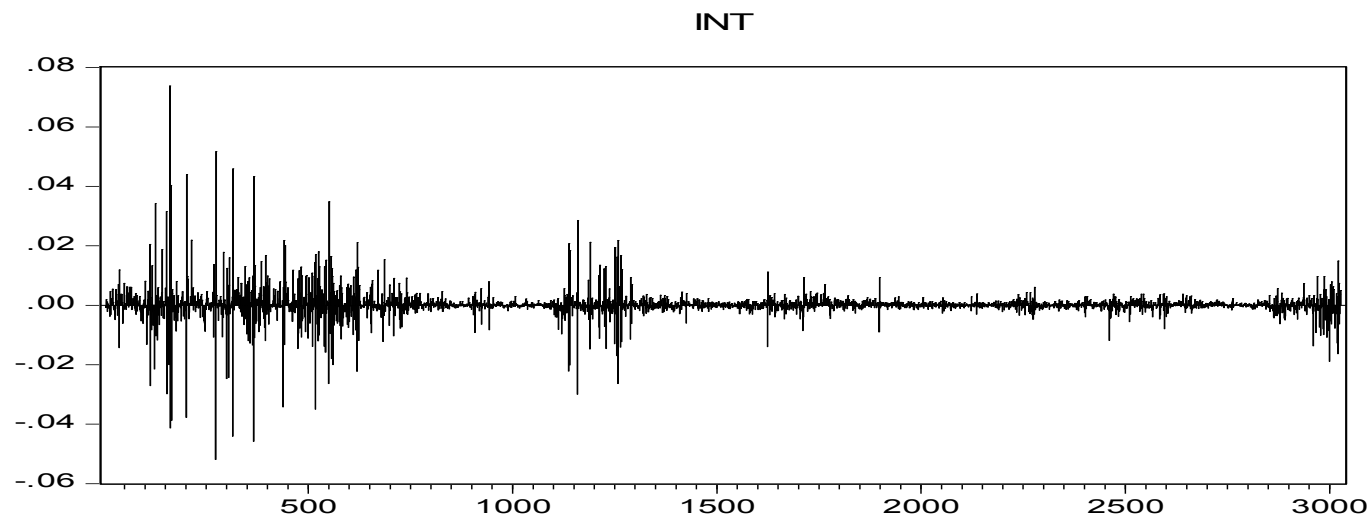

Figure 2. Return series of interest rate

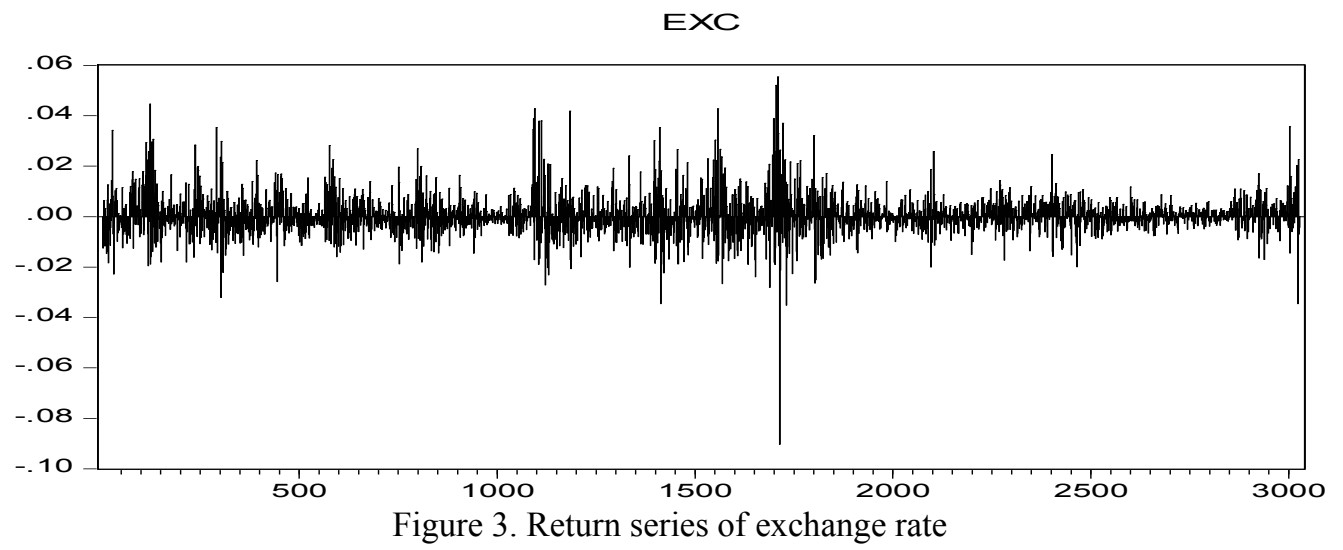

From Figures of return series (Figure 1 to 3 ), it can be observed that all the return series' volatilities change with time and also exhibits positive serial correlation or "volatility clustering". It is also perceived that large changes tend to be followed by large changes and small changes tend to be followed by small changes, which mean volatility clustering is observed in financial returns data. The persisting of volatility clustering rejects the random walk hypothesis. Besides, the volatility clusters of return series may be the exhibit of a long-memory process. 
Augmented Dickey Fuller (ADF) unit root test has been applied to check whether the series are stationary or not. Stationary condition of series has been tested by using ADF (Dickey \& Fuller, 1981; Gujarati, 2003; Enders, 1995).

$$
\Delta Y t=b 0+\beta Y t-1+\mu 1 \Delta Y t-1+\mu 2 \Delta Y t-2+\ldots+\mu p \Delta Y t-p+e t
$$

$Y_{t}$ represents time series to be tested, $b_{0}$ is the intercept term, $\beta$ is the coefficient of interest in the unit root test, $\mu_{i}$ is the parameter of the augmented lagged first difference of $Y_{t}$ to represent the pth-order autoregressive process, and $e_{t}$ is the white noise error term.

Table 2. ADF unit root test statistics

\begin{tabular}{clccccc}
\hline & Include test equation & \multirow{2}{*}{ Test statistics } & \multirow{2}{*}{ Prob* } & \multicolumn{3}{c}{ Test critical values } \\
\cline { 4 - 6 } & & & & $1 \%$ level & $5 \%$ level & $10 \%$ level \\
\hline \multirow{3}{*}{ BIST } & without constant and linear trend & -53.41434 & 0.0001 & -2.565902 & -1.940953 & -1.616613 \\
& with constant & -53.45691 & 0.0001 & -3.432814 & -2.862514 & -2.567334 \\
& with constant and linear trend & -53.45216 & 0.0000 & -3.961775 & -3.411635 & -3.127690 \\
\multirow{5}{*}{ Interest Rate } & without constant and linear trend & -56.38988 & 0.0001 & -2.565902 & -1.940953 & -1.616613 \\
& with constant & -56.44635 & 0.0001 & -3.432814 & -2.862514 & -2.567334 \\
& with constant and linear trend & -56.64515 & 0.0000 & -3.961775 & -3.411635 & -3.127690 \\
\multirow{2}{*}{ Exchange Rate } & without constant and linear trend & -53.40452 & 0.0001 & -2.565902 & -1.940953 & -1.616613 \\
& with constant & -53.43817 & 0.0001 & -3.432814 & -2.862514 & -2.567334 \\
& with constant and linear trend & -53.44132 & 0.0000 & -3.961775 & -3.411635 & -3.127690 \\
\hline
\end{tabular}

Note. *MacKinnon (1996) one-sided p-values. **Looked over until 26 lags in terms of Schwarz info criterion. ***BIST and Exchange Rate series are logaritmic return series.

Table 2 shows the result of ADF unit root tests on the original series as well as the MacKinnon critical values for rejection of the hypothesis of the existence of a unit root at the $1 \%$ level of significance. Since the ADF test statistics are larger in absolute values than the critical values, we reject the hypothesis of non-stationarity. Therefore, it can be concluded that stock returns as well as exchange rates and interest rates are both found stationary at their level form.

\subsection{Determining the Mean Equations}

Since the series are found to be stationary, our next objective is to determine if the returns of return series can be forecasted by its own past values. ARMA $(0,0)$ model is found the best fitting model for forecasting the exchange rate and stock returns as well. On the other hand, ARMA $(2,0)$ is best suited model for forecasting interest rate returns.

Table 3.1. Schwarz information criterions for finding best fitting ARMA model of BIST-100's mean equation

\begin{tabular}{ccccc}
\hline $\mathrm{AR} / \mathrm{MA}$ & 0 & 1 & 2 & 3 \\
\hline 0. & $\mathbf{- 5 . 5 7 7 0 5 2}$ & -5.575183 & -5.572748 & -5.570198 \\
1 & -5.575210 & -5.575588 & -5.570120 & -5.570851 \\
2 & -5.572711 & -5.573427 & -5.570951 & -5.568316 \\
3 & -5.570164 & -5.570828 & -5.568315 & -5.568916 \\
\hline
\end{tabular}

Table 3.2. Schwarz information criterions for finding best fitting ARMA model of interest rate's mean equation

\begin{tabular}{lllll}
\hline AR / MA & 0.000000 & 1.000000 & 2.000000 & 3.000000 \\
\hline 0.000000 & -7.756223 & -7.946336 & -7.944477 & -7.945441 \\
1.000000 & -7.909017 & -7.943961 & -7.944237 & -7.947625 \\
2.000000 & $-\mathbf{7 . 9 5 0 8 6 7}$ & -7.948341 & -7.947683 & -7.945032 \\
3.000000 & -7.948009 & -7.946814 & -7.944750 & -7.942138 \\
\hline
\end{tabular}


Table 3.3. Schwarz information criterions for finding best fitting ARMA model of exchange rate's mean equation

\begin{tabular}{ccccc}
\hline $\mathrm{AR} / \mathrm{MA}$ & 0 & 1 & 2 & 3 \\
\hline 0 & $\mathbf{- 6 . 8 2 6 0 3 4}$ & -6.824234 & -6.823312 & -6.821431 \\
1 & -6.824681 & -6.823167 & -6.821317 & -6.819387 \\
2 & -6.823429 & -6.821418 & -6.823394 & -6.820080 \\
3 & -6.821635 & -6.821231 & -6.819726 & -6.817937 \\
\hline
\end{tabular}

SIC always gives penalty for the additional parameters more than AIC does. So ARMA $(0,0)$ model is chosen for BIST and Exchange Rate and ARMA $(2,0)$ for Interest Rate as the mean equation mainly take account of the SIC. Therefore, the conditional mean equation with error term following conditional heteroscedasticity process is modeled for BIST and Exchange return series as;

$$
y_{i t}=c_{i t}
$$

And for Interest rate return series as;

$$
y_{i t}=\phi_{1} y_{i, t-1}+\phi_{2} y_{i, t-2}+\varepsilon_{i t}
$$

\subsection{GARCH Models}

After estimating the correct ARMA model, ARCH-LM test was applied to see whether any conditional heteroscedasticity (ARCH effect) exists within the models. In order to test whether BIST-100 Index, interest rate and exchange rate return series are remaining ARCH effects in the residuals a Lagrange Multiplier test (Engle, 1982) is applied to all data set. Results of the Lagrange Multiplier (LM) test for ARCH disturbances indicated significant evidence of ARCH effects for all data set.

Table 4. Heteroscedasticity test: ARCH LM test

\begin{tabular}{lcccc}
\hline & F statistics & Prob & Obs R squared & prob \\
\hline BIST & 134.0769 & 0.0000 & 128.4642 & 0.0000 \\
Interest Rate & 214.8891 & 0.0000 & 200.7516 & 0.0000 \\
Exchange Rate & 74.52998 & 0.0000 & 72.78370 & 0.0000 \\
\hline
\end{tabular}

The ARCH(1), GARCH $(1,1)$, TARCH(1,1), GARCH-M(1,1), E-GARCH(1,1), PARCH(1,1), CGARCH(1,1) and AGARCH(1,1) models are estimated for the series of stock market, interest rates and exchange rate returns respectively to choose the best fitting volatility for forecasting the conditional volatility of the return series. Finally, in order to test whether there are any remaining ARCH effects in the residuals is calculated by regressing the squared residuals on a constant and $p$ lags. The correct number of lags in the model have been selected using AIC and SIC information criterion. The results show that there is no persisting of ARCH effect in the residuals except EGARCH(1,1) model for BIST and TARCH(1,1), EGARCH $(1,1)$ and $\operatorname{PARCH}(1,1)$ model for Interest rate at $5 \%$ significant level. We used $5 \%$, which is the standard level of significance, to justify a claim of statistically significant effect at all tests.

Overall, using the minimum SIC, maximum likelihood (ML) values as model selection criteria are performed. According to the results given in Table 5-6-7, CGARCH model seems to be the best model to forecast volatility of both interest rate and exchange rate markets. While TARCH model can be used in order to forecast volatility of BIST-100 Index. Although SIC value of BIST's EGARCH $(1,1)$ model is the smallest, the model still shows ARCH effect. So that the second smallest SIC value model was preferred as the best fitting model for forecasting the volatility of BIST. 
Table 5. Coefficients (Prob.) for ARMA $(0,0)$ GARCH Models of BIST

\begin{tabular}{|c|c|c|c|c|c|c|c|c|}
\hline & $\begin{array}{l}\mathrm{ARCH} \\
(1) \\
\end{array}$ & $\begin{array}{c}\text { GARCH } \\
(1,1) \\
\end{array}$ & $\begin{array}{c}\text { TARCH } \\
(\mathbf{1 , 1}) \\
\end{array}$ & $\begin{array}{l}\text { GARCH in } \\
\text { Mean }(1,1)\end{array}$ & $\begin{array}{c}\text { EGARCH } \\
(1,1) \\
\end{array}$ & $\begin{array}{c}\text { PARCH } \\
(1,1) \\
\end{array}$ & $\begin{array}{c}\text { CGARCH } \\
(1,1) \\
\end{array}$ & $\begin{array}{c}\text { AGARCH } \\
(1,1) \\
\end{array}$ \\
\hline$\alpha_{0}$ (constant) & $\begin{array}{r}0.000159 \\
(0.0000)\end{array}$ & $\begin{array}{l}4.38 \mathrm{E}-06 \\
(0.0000)\end{array}$ & $\begin{array}{l}5.95 \mathrm{E}-06 \\
(0.0000)\end{array}$ & $\begin{array}{l}4.31 \mathrm{E}-06 \\
(0.0000)\end{array}$ & $\begin{array}{c}-0.459288 \\
(0.0000)\end{array}$ & $\begin{array}{l}4.21 \mathrm{E}-05 \\
(0.0163)\end{array}$ & $\begin{array}{l}0.000313 \\
(0.0000)\end{array}$ & $\begin{array}{c}0.000306 \\
(0.0000)\end{array}$ \\
\hline$\alpha(\mathrm{ARCH})$ & $\begin{array}{l}0.318831 \\
(0.0000)\end{array}$ & $\begin{array}{l}0.105392 \\
(0.0000)\end{array}$ & $\begin{array}{c}0.061823 \\
(0.0000)\end{array}$ & $\begin{array}{c}0.104684 \\
(0.0000)\end{array}$ & $\begin{array}{c}0.200757 \\
(0.0000)\end{array}$ & $\begin{array}{c}0.108897 \\
(0.0000)\end{array}$ & $\begin{array}{l}0.083987 \\
(0.0000)\end{array}$ & $\begin{array}{c}0.049748 \\
(0.0421)\end{array}$ \\
\hline ૪ (Asymm-int) & & & $\begin{array}{c}0.092649 \\
(0.0000)\end{array}$ & & $\begin{array}{c}-0.077591 \\
(0.0000)\end{array}$ & $\begin{array}{c}0.293249 \\
(0.0000)\end{array}$ & & $\begin{array}{r}0.016247 \\
(0.4222)\end{array}$ \\
\hline$\beta(\mathrm{GARCH})$ & & $\begin{array}{l}0.880598 \\
(0.0000)\end{array}$ & $\begin{array}{c}0.867068 \\
(0.0000)\end{array}$ & $\begin{array}{c}0.881656 \\
(0.0000)\end{array}$ & $\begin{array}{c}0.964328 \\
(0.0000)\end{array}$ & $\begin{array}{c}0.875496 \\
(0.0000)\end{array}$ & $\begin{array}{c}0.859194 \\
(0.0000)\end{array}$ & $\begin{array}{c}0.457643 \\
(0.0142)\end{array}$ \\
\hline$\beta_{1}$ & & & & $\begin{array}{c}-1.457497 \\
(0.4796)\end{array}$ & & & & \\
\hline$\delta$ & & & & & & $\begin{array}{c}1.551095 \\
(0.0000)\end{array}$ & & \\
\hline$P$ & & & & & & & $\begin{array}{c}0.995094 \\
(0.0000)\end{array}$ & $\begin{array}{c}0.988529 \\
(0.0000)\end{array}$ \\
\hline$\Phi$ & & & & & & & $\begin{array}{l}0.017021 \\
(0.0073)\end{array}$ & $\begin{array}{c}0.090405 \\
(0.0000)\end{array}$ \\
\hline AIC & -5.655031 & -5.815022 & -5.824298 & -5.814591 & -5.825939 & -5.825465 & -5.758870 & -5.815851 \\
\hline SIC & -5.649064 & -5.807067 & -5.814354 & -5.804647 & -5.815994 & -5.813532 & -5.744397 & -5.801929 \\
\hline $\begin{array}{c}\text { F statistics of } \\
\text { ARCH LM test }\end{array}$ & $\begin{array}{l}0.846327 \\
(0.3577)\end{array}$ & $\begin{array}{l}3.096349 \\
(0.0786)\end{array}$ & $\begin{array}{l}1.311606 \\
(0.2522)\end{array}$ & $\begin{array}{l}3.365527 \\
(0.0667)\end{array}$ & $\begin{array}{l}6.240938 \\
(0.0125)\end{array}$ & $\begin{array}{c}3.367725 \\
(0.0666)\end{array}$ & $\begin{array}{l}3.790594 \\
(0.0517)\end{array}$ & $\begin{array}{l}0.756599 \\
(0.38451) \\
\end{array}$ \\
\hline
\end{tabular}

Table 6. Coefficients (prob.) for ARMA(2,0) GARCH models of interest rate

\begin{tabular}{|c|c|c|c|c|c|c|c|c|}
\hline & $\begin{array}{c}\mathrm{ARCH} \\
(1) \\
\end{array}$ & $\begin{array}{c}\text { GARCH } \\
(1,1) \\
\end{array}$ & $\begin{array}{c}\text { TARCH } \\
(1,1)\end{array}$ & $\begin{array}{l}\text { GARCH in } \\
\text { Mean }(1,1) \\
\end{array}$ & $\begin{array}{c}\text { EGARCH } \\
(1,1) \\
\end{array}$ & $\begin{array}{c}\text { PARCH } \\
(1,1) \\
\end{array}$ & $\begin{array}{c}\text { CGARCH } \\
(\mathbf{1 , 1}) \\
\end{array}$ & $\begin{array}{c}\text { AGARCH } \\
(1,1) \\
\end{array}$ \\
\hline$\alpha_{0}$ (constant) & $\begin{array}{l}3.55 \mathrm{E}-06 \\
(0.0000)\end{array}$ & $\begin{array}{c}1.12 \mathrm{E}-08 \\
(0.0000)\end{array}$ & $\begin{array}{l}1.13 \mathrm{E}-08 \\
(0.0000)\end{array}$ & $\begin{array}{c}1.22 \mathrm{E}-08 \\
(0.0000)\end{array}$ & $\begin{array}{c}-0.145989 \\
(0.0000)\end{array}$ & $\begin{array}{l}3.10 \mathrm{E}-08 \\
(0.7878)\end{array}$ & $\begin{array}{l}0.016859 \\
(0.0001)\end{array}$ & $\begin{array}{c}0.001744 \\
(0.4993)\end{array}$ \\
\hline$\alpha(\mathrm{ARCH})$ & $\begin{array}{l}2.969807 \\
(0.0000)\end{array}$ & $\begin{array}{c}0.158291 \\
(0.0000)\end{array}$ & $\begin{array}{l}0.166053 \\
(0.0000)\end{array}$ & $\begin{array}{c}0.168398 \\
(0.0000)\end{array}$ & $\begin{array}{l}0.245433 \\
(0.0000)\end{array}$ & $\begin{array}{l}0.139201 \\
(0.0000)\end{array}$ & $\begin{array}{l}0.275689 \\
(0.0000)\end{array}$ & $\begin{array}{l}-0.04237 \\
(0.0039)\end{array}$ \\
\hline ૪ (Asymm-int) & & & $\begin{array}{c}-0.012493 \\
(0.1476)\end{array}$ & & $\begin{array}{c}-0.011186 \\
(0.0254)\end{array}$ & $\begin{array}{l}0.078837 \\
(0.0000)\end{array}$ & & $\begin{array}{r}0.305047 \\
(0.0000)\end{array}$ \\
\hline$\beta(\mathrm{GARCH})$ & & $\begin{array}{c}0.885308 \\
(0.0000)\end{array}$ & $\begin{array}{c}0.884297 \\
(0.0000)\end{array}$ & $\begin{array}{l}0.879127 \\
(0.0000)\end{array}$ & $\begin{array}{l}1.001094 \\
(0.0000)\end{array}$ & $\begin{array}{c}0.913759 \\
(0.0000)\end{array}$ & $\begin{array}{l}0.260700 \\
(0.0000)\end{array}$ & $\begin{array}{c}0.156071 \\
(0.0000)\end{array}$ \\
\hline$\beta_{1}$ & & & & $\begin{array}{c}10.68016 \\
(0.0000)\end{array}$ & & & & \\
\hline$\delta$ & & & & & & $\begin{array}{l}1.380227 \\
(0.0000)\end{array}$ & & \\
\hline $\mathrm{P}$ & & & & & & & $\begin{array}{c}0.999999 \\
(0.0000)\end{array}$ & $\begin{array}{c}0.999994 \\
(0.0000)\end{array}$ \\
\hline$\Phi$ & & & & & & & $\begin{array}{c}0.059911 \\
(0.0000)\end{array}$ & $\begin{array}{r}0.063377 \\
(0.0000)\end{array}$ \\
\hline AIC & -8.551125 & -9.218027 & -9.217510 & -9.222072 & -9.220927 & -9.221516 & -9.258319 & -9.256891 \\
\hline SIC & -8.541181 & -9.206093 & -9.203588 & -9.208150 & -9.205016 & -9.205605 & -9.242409 & -9.238991 \\
\hline $\begin{array}{c}\text { F statistics of } \\
\text { ARCH LM } \\
\text { test }\end{array}$ & $\begin{array}{c}1.063776 \\
(0.3024)\end{array}$ & $\begin{array}{c}3.756694 \\
(0.0527)\end{array}$ & $\begin{array}{c}4.016908 \\
(0.0451)\end{array}$ & $\begin{array}{c}2.556375 \\
(0.1100)\end{array}$ & $\begin{array}{c}9.941334 \\
(0.0016)\end{array}$ & $\begin{array}{c}10.10539 \\
(0.0015)\end{array}$ & $\begin{array}{c}0.105557 \\
(0.7453)\end{array}$ & $\begin{array}{c}0.677591 \\
(0.4105)\end{array}$ \\
\hline
\end{tabular}

Table 7. Coefficients (prob.) for ARMA $(0,0)$ GARCH models of exchange rate

\begin{tabular}{ccccccccc}
\hline & ARCH & GARCH & TARCH & GARCH in & EGARCH & PARCH & CGARCH & AGARCH \\
& $(1)$ & $(1,1)$ & $(1,1)$ & Mean $(1,1)$ & $(1,1)$ & $(1,1)$ & $(\mathbf{1 , 1})$ & $(1,1)$ \\
\hline \multirow{2}{*}{$\alpha_{0}$ (constant) } & $4.07 \mathrm{E}-05$ & $1.20 \mathrm{E}-06$ & $1.36 \mathrm{E}-06$ & $1.21 \mathrm{E}-06$ & -0.604997 & $8.87 \mathrm{E}-06$ & $\mathbf{0 . 0 0 0 9 8 0}$ & 0.000206 \\
& $(0.0000)$ & $(0.0000)$ & $(0.0000)$ & $(0.0000)$ & $(0.0000)$ & $(0.1254)$ & $\mathbf{( 0 . 6 3 6 6 )}$ & $(0.0028)$ \\
\hline
\end{tabular}




\begin{tabular}{|c|c|c|c|c|c|c|c|c|}
\hline$\alpha(\mathrm{ARCH})$ & $\begin{array}{c}0.434313 \\
(0.0000)\end{array}$ & $\begin{array}{c}0.206905 \\
(0.0000)\end{array}$ & $\begin{array}{c}0.258533 \\
(0.0000)\end{array}$ & $\begin{array}{l}0.207697 \\
(0.0000)\end{array}$ & $\begin{array}{c}0.313310 \\
(0.0000)\end{array}$ & $\begin{array}{l}0.189012 \\
(0.0000)\end{array}$ & $\begin{array}{c}0.147386 \\
(0.0000)\end{array}$ & $\begin{array}{c}0.000342 \\
(0.8033)\end{array}$ \\
\hline ૪ (Asymm-int) & & & $\begin{array}{c}-0.127179 \\
(0.0000)\end{array}$ & & $\begin{array}{l}0.085233 \\
(0.0000)\end{array}$ & $\begin{array}{c}-0.205113 \\
(0.0000)\end{array}$ & & $\begin{array}{c}0.051138 \\
(0.0099)\end{array}$ \\
\hline$\beta(\mathrm{GARCH})$ & & $\begin{array}{c}0.795229 \\
(0.0000)\end{array}$ & $\begin{array}{c}0.798108 \\
(0.0000)\end{array}$ & $\begin{array}{c}0.794506 \\
(0.0000)\end{array}$ & $\begin{array}{l}0.963366 \\
(0.0000)\end{array}$ & $\begin{array}{c}0.812665 \\
(0.0000)\end{array}$ & $\begin{array}{l}0.784450 \\
(0.0000)\end{array}$ & $\begin{array}{c}0.948178 \\
(0.0000)\end{array}$ \\
\hline$\beta_{1}$ & & & & $\begin{array}{c}-1.674742 \\
(0.5144)\end{array}$ & & & & \\
\hline$\delta$ & & & & & & $\begin{array}{l}1.637558 \\
(0.0000)\end{array}$ & & \\
\hline $\mathrm{P}$ & & & & & & & $\begin{array}{l}0.999865 \\
(0.0000)\end{array}$ & $\begin{array}{c}0.932469 \\
(0.0000)\end{array}$ \\
\hline$\Phi$ & & & & & & & $\begin{array}{c}0.057658 \\
(0.0000)\end{array}$ & $\begin{array}{c}0.152866 \\
(0.0000)\end{array}$ \\
\hline AIC & -6.942788 & -7.252273 & -7.261466 & -7.251747 & -7.260296 & -7.261923 & -7.267572 & -7.267283 \\
\hline SIC & -6.936822 & -7.244318 & -7.251522 & -7.241803 & -7.250352 & -7.249990 & -7.255639 & -7.253361 \\
\hline $\begin{array}{l}\text { F statistics of } \\
\text { ARCH LM test }\end{array}$ & $\begin{array}{l}0.352851 \\
(0.5525)\end{array}$ & $\begin{array}{l}1.145304 \\
(0.2846)\end{array}$ & $\begin{array}{l}0.616185 \\
(0.4325)\end{array}$ & $\begin{array}{l}1.124457 \\
(0.2890)\end{array}$ & $\begin{array}{c}2.669880 \\
(0.1024)\end{array}$ & $\begin{array}{c}1.363852 \\
(0.5445)\end{array}$ & $\begin{array}{c}0.921853 \\
(0.3371)\end{array}$ & $\begin{array}{l}0.981555 \\
(0.3219)\end{array}$ \\
\hline
\end{tabular}

The ARCH parameter $(\alpha)$, and GARCH parameter $(\beta)$ are positive and significant in all eight models, indicating the presence of ARCH and GARCH effects in the returns of stocks, interest rates and exchange rates.

The significant parameter for the asymmetric volatility response in EGARCH models $(\gamma)$ is negative for interest rate and BIST but positive for exchange rate. The negative $\gamma$ parameter in EGARCH models indicating an asymmetric response for positive returns in the conditional variance equation. Also the positive $(\gamma)$ value in TGARCH $(1,1)$ model of BIST shows the presence of leverage effect in stock market. Positive and significant $\gamma$ in TARCH models shows us that leverage effect exists and bad news increases volatility.

As it is seen in C-Garch Models, transitory (short-run) volatility $(\beta)$ is much lower for interest rate than for BIST and exchange rate. On the other hand, the difference between transitory volatility for the three financial indices is implying faster decay and convergence to long-run volatility for all indices. $\rho$ values in the CGARCH models are quite bigger indicating that indices have persisting volatility and $q_{t}$ approaches $\varepsilon$ very slowly.

\section{Conculusion}

This study applies symmetric and several asymmetric volatility models as a metric for the specification of conditional volatility of stock market, exchange rate and interest rate returns for the first time in Turkish financial markets for 2002 to 2014.

One of the main results of this paper is to point out that all GARCH family models show evidence of asymmetric effects in each market data. The estimated $\beta(\mathrm{GARCH})$ coefficients are quite bigger than 0.7 means that old news has a quite persistent effect on volatility.

Besides, for TARCH, EGARCH, PARCH and AGARCH models of stock returns, the sum of the coefficients $\alpha$ and $\beta$ is less than one, implying that, although it takes a long time, the volatility process does return to its mean. For, interest and exchange rate markets this sum is bigger than one shows asymmetric GARCH models are more suitable in modeling the volatility.

The $\gamma$ values of best fitting model for BIST (TARCH $(1,1))$ is positive and significant which also shows us that leverage effect exists, bad news increases volatility. On the other hand, asymmetric coefficients of the best model of exchange interest rate are statistically significant but sign of coefficient is negative shows asymmetric response for positive returns in the conditional variance equation.

BIST and Interest rate returns are affected more by the last period's forecast variance than the foreign exchange markets return, because their $\beta$ values (The GARCH term) are bigger than the exchange rates' $\beta$ values.

It can be explained as interest rate market is more stable than the other markets.

We have exhibited that using asymmetric GARCH models when estimating and forecasting financial time series with high frequency can improve the results of the models. Because findings of the study showed that asymmetric GARCH models performed better in forecasting the volatility of financial assets than the classic model. 
Since conditional volatility is more persistent for all indices then modeling of prediction of volatility by CGARCH or other models that takes long memory into consideration is relatively more important for the valuations of financial assets.

The results of our study are coherent to the facts which have been reported in Bollerslev et al. (1994) and Pagan (1996). Return series of Turkish financial markets include leptokurtosis, leverage effects, volatility clustering and long memory.

\section{References}

Akgül, I., \& Sayyan, H. (2005). Forecasting volatility in ISE-30 stock returns with asymmetric conditional heteroskedasticity models. Symposium of Traditional Finance, Marmara Universitesi Bankac1lık ve Sigortacılık Yüksekokulu, Istanbul, Turkey.

Ane, T. (2006). Short and long term components of volatility in Hong Kong stock returns. Applied Financial Economics, 16(6), 439-460. http://dx.doi.org/10.1080/0960310050039720

Angabini, A., \& Wasiuzzaman, S. (2011). GARCH models and the financial crisis - a study of the Malaysian stock market. The International Journal of Applied Economics and Finance, 5(3), 226-236. http://dx.doi.org/10.3923/ijaef.2011.226.236

Awartani, B. M. A., \& Corradi, V. (2005). Predicting the volatility of the S\&P-500 stock index via GARCH Models: The role of asymmetries. International Journal of Forecasting, 21, 167-183. http://dx.doi.org/10.1016/j.ijforecast.2004.08.003

Aydın, K. (2002). Riske maruz değer hesaplamalarında EWMA ve GARCH metodlarının kullanılmasl: IMKB-30 endeks uygulaması. Yayımlanmamış Yüksek Lisans Tezi, Sosyal Bilimler Enstitüsü, Karaelmas Üniversitesi, Zonguldak.

Balaban, E. (2004). Comparative forecasting performance of symmetric and asymmetric conditional volatility models of an exchange rate. Economics Letters, 83(1), 99-105. http://dx.doi.org/10.2139/ssrn.339521

Black, F. (1976). Studies of stock price volatility changes (pp. 177-181). Proceedings of the 1976 Business Meeting of the Business and Economics Statistics Section. American Statistical Association, Washington, DC.

Bollerslev, T. (1986). Generalized autoregressive conditional heteroskedasticity. Journal of Econometrics, 31(3), 307-327. http://dx.doi.org/10.1016/0304-4076(86)90063-1

Bollerslev, T., Engle, R. F., \& Nelson, D. (1994). ARCH models. In R. Engle \& D. McFadden (Eds.), Handbook of econometrics (pp. 2959-3038). Amsterdam: North Holland Press.

Brooks, C. (2002). Introductory econometrics for finance. Cambridge: Cambridge University Press.

Çağıl, G., \& Okur, M. (2010). 2008 Küresel Krizinin İMKB hisse senetleri üzerinde etkilerinin GARCH modelleri ile analizi. Marmara Üniversitesi İ̈BF Dergisi, 28(1), 573-585.

Caporin, M., \& McAleer, M. (2006). Dynamic asymmetric GARCH. Journal of Financial Econometrics, 4(3), 385-412. http://dx.doi.org/10.1093/jjfinec/nbj011

CBRT. (2014). Central bank of the Republic of Turkey web site. Retrieved from http://www.tcmb.gov.tr

Chen, S. W., \& Shen, C. H. (2004). GARCH, jumps and permanent and transitory components of volatility: The case of the Taiwan exchange rate. Mathematics and Computers in Simulation, 67(3), 201-216. http://dx.doi.org/10.1016/j.matcom.2004.06.006

Christie, A. A. (1982). The Stochastic behavior of common stock variances-value, leverage and interest rate $\begin{array}{lllll}\text { effects. Journal of } & \text { Financial }\end{array}$ http://dx.doi.org/10.1016/0304-405X(82)90018-6

Dallah, H. (2011). Investigating the volatility of Nigerian currency against major developed world (G-4) currency exchange rates returns. International Journal of Academic Research, 3(3), 267-278.

Dickey, D. A., \& Fuller, W. A. (1981). Likelihood ratio statistics for autoregressive time series with a unit root. Econometrica, 49(4), 1057-1072. http://dx.doi.org/10.2307/1912517

Ding, Z., Granger, C. W. J., \& Angle, R. F. (1993). A long memory property of stocks market returns and a new Model. Journal of Empirical Finance, 1(1), 83-106. http://dx.doi.org/10.1016/0927-5398(93)90006-D 
Enders, W. (1995). Applied economic time series. New York: Wiley Inc.

Engle, R. F. (1982). Autoregressive conditional heteroscedasticity with estimates of the variance of United Kingdom inflation. Econometrica, 50(4), 987-1007. http://dx.doi.org/10.2307/1912773

Engle, R., \& Lee, G. (1993). A permanent and transitory component model of stock return volatility. University of California at San Diego, Discussion Paper 92-44R.

Fernandez, A., \& Arago, V. (2003). European volatility transmission with structural changes in variance. Retrieved from http://xiforofinanzas.ua.es /trabajos/1039.pdf

Glosten, L. R., Jagannathan, R., \& Runkle, D. E. (1993). On the relation between expected value and the volatility of the nominal excess return on stocks. Journal of Finance, 48(5), 1779-1801. http://dx.doi.org/10.1111/j.1540-6261.1993.tb05128.x

Gökçe, A. (2001). İstanbul menkul kıymetler borsası getirilerindeki volatilitenin ARCH teknikleri ile ölçülmesi. Gazi Üniversitesi İ.I.B.. Dergisi, 1, 35-58.

Grier, K. B., \& Perry, M. J. (1998). On inflation and inflation uncertainty in the G7 countries. Journal of International Money and Finance, 17, 671-689. http://dx.doi.org/10.1016/S0261-5606(98)00023-0

Gujarati, D. N. (2003). Basic econometrics. India: McGraw Hill.

Harris, R., \& Sollis, R. (2003). Applied time series modelling and forecasting. England: John Wiley and Sons Ltd.

Hien, M., \& Thanh, T. (2008). Modelling and forecasting volatility by GARCH type Models: The case of Vietnam stock exchange. MA Dissertation thesis, University of Nottingham. Retrieved from http://edissertations.nottingham.ac.uk/2017/1/08 MAlixhm7.pdf

Kang, S. H., Kang, S. M., \& Yoon, S. M. (2009). Forecasting volatility of crude oil markets. Energy Economics, 31(1), 119-125. http://dx.doi.org/10.1016/j.eneco

Kıran, B. (2011). Döviz kuru volatilitesinin asimetrik üslü ARCH (APARCH) modeli ile tahmini. Retrieved from http://fbe.emu.edu.tr/journal/doc/11-12/01.pdf

Kontonikas, A. (2004). Inflation and inflation uncertainty in the United Kingdom, evidence from GARCH modelling. Economic Modelling, 21(3), 525-543. http://dx.doi.org/10.1016/j.econmod.2003.08.001

Kovacic, Z. J. (2008). Forecasting volatility: Evidence from the Macedonian stock exchange. International Research Journal of Finance and Economics, 18, 182-212.

Lee, H. J. (2009). Forecasting performance of asymmetric GARCH stock market volatility models. Journal of International Economic Studies, 13(2), 109-142. http://dx.doi.org/10.11644/KIEP.JEAI.2009.13.2.203

MacKinnon, J. G. (1996). Numerical distribution functions for unit root and cointegration tests. Journal of Applied Econometrics, 11(6), 601-618. http://dx.doi.org/10.1002/(SICI)1099-1255(199611)11:6

Makridakis, S., Wheelwright, S. C., \& Hyndman, R. J. (1998). Forecasting: Methods and applications (3rd ed.). New York: John Wiley \& Sons.

Mandelbrot, B. (1963). The variation of certain speculative prices. Journal of Business, 36(4), 394-419. http://dx.doi.org/10.1086/294632

Mazıbaş, M. (2011), IMKB piyasalarındaki volatilitenin modellenmesi ve öngörülmesi: Asimetrik GARCH modelleri ile bir uygulama. Retrieved from http://www.ekonometridernegi.org/bildiriler/o16s3.pdf

Miron, D., \& Tudor, C. (2010). Asymmetric conditional volatility models: Empirical estimation and comparison of forecasting accuracy. Romanian Journal of Economic Forecasting, 3, 74-92.

Nelson, D. B. (1991). Conditional heteroskedasticity in asset returns: A new approach. Econometrica, 59(2), 347-370. http://dx.doi.org/10.2307/2938260

Öztürk, K. (2010). Döviz kuru oynakllğı ve döviz kuru oynakllğının faiz oranı oynaklı̆̆ ile olan ilişkisi: Türkiye örneği. Proficiency Thesis for Excellence, Central Bank of the Republic of Turkey. Retrieved from http://www.tcmb.gov.tr/kutuphane/ TURKCE/tezler/kevserozturk.pdf

Pagan, A. R. (1996). The econometrics of financial markets. Journal of Empirical Finance, 3(1), 15-102. http://dx.doi.org/10.1016/0927-5398(95)00020-8

Peters, J. P. (2001). Estimating and forecasting volatility of stock indices using asymmetric GARCH models and (skewed) student-t densities. Working Paper, EAA Business School, University of Liège. Retrieved 
from

http://www.unalmed.edu.co/ ndgirald/Archivos\%20Lectura/Archivos\%20curso\%20Series\%20II/jppeters .pdf

Sandoval, J. (2006). Do asymmetric GARCH models fit better exchange rate volatilities on emerging markets? Retrieved from http://foros.uexternado.edu.co/ecoinstitucional/index.php/odeon/article/viewFile/2654/2302

Santis, G. D., \& Imrohoroglu, S. (1997). Stock returns and volatility in emerging financial markets. Journal of International Money and Finance, 16(4), 561-579. http://dx.doi.org/10.1016/S0261-5606(97)00020-X

$\mathrm{Su}, \mathrm{C}$. (2010). Application of EGARCH model to estimate financial volatility of daily returns: The empirical case of China. University of Gothenburg, Master Degree Project No. 2010:142.

Wang, J., \& Yang, M. (2009). Asymmetric volatility in the foreign exchange markets. Journal of International Financial Markets, Institutions and Money, 19(4), 597-615. http://dx.doi.org/10.1016/j.intfin.2008.10.001

Watanabe, T., \& Harada, K. (2006). Effects of the bank of Japan's intervention on Yen/Dollar exchange rate volatility. J. Japanese Int. Economies, 20(1), 99-111. http://dx.doi.org/10.1016/j.jjie.2004.08.001

Yalama, A., \& Sevil, G. (2008). Forecasting world stock markets volatility. International Research Journal of Finance and Economics, 15, 159-174.

Zakoian, J. M. (1994). Threshold heteroskedasticity models. Journal of Economic Dynamics and Control, 18(5), 931-955. http://dx.doi.org/10.1016/0165-1889(94)90039-6

\section{Notes}

Note 1. 'Volatility Clustering' or 'Volatility Pooling' describes the tendency of large changes in asset prices (of either sign) to follow large changes and small changes (of either sign) to follow small changes. In other words, the current level of volatility tends to be positively correlated with its level during the immediately preceding periods (Brooks, 2002).

Note 2. See, Black (1976) and Christie (1982).

Note 3. Long-memory: The presence of statistically significant correlations between observations that are a large distance apart.

Note 4. Random Walk (RW): It is the simple historical price model. If change in volatility is iid $(\mathrm{N} \sim(0, \sigma))$, then volatility forecast can be based on any period in the past, although in practice one often uses the time t-1 value to predict time t volatility. Ordinary Least Squares (OLS): Extending the idea of the random walk model, under the assumption of a stationary mean, the volatility forecast can be based on the long-term average of past observed volatilities (Makridakis et. al., 1998).

Note 5. BIST-30 Index (for more knowledge look at Note 6).

Note 6. Index includes the 30 shares with the highest capitalization traded in Istanbul Stock Exchange

Note 7. ISE is Istanbul Stock Exchange market and BIST-100 Index is determined as a Turkish stock market indicator.

Note 8. Foreign exchange rate basket, formed by Central Bank of Turkish Republic (CBRT) as combination of Euro and dollar $(0.50 \$+0.50 €)$.

\section{Copyrights}

Copyright for this article is retained by the author(s), with first publication rights granted to the journal.

This is an open-access article distributed under the terms and conditions of the Creative Commons Attribution license (http://creativecommons.org/licenses/by/3.0/). 